\title{
An exploration of the role of communication during the in-crisis situation
}

\begin{tabular}{|c|c|}
\hline \multicolumn{2}{|c|}{$\begin{array}{l}\text { Author: } \\
\text { Tanya le Roux }{ }^{1}\end{array}$} \\
\hline \multicolumn{2}{|c|}{$\begin{array}{l}\text { Affiliation: } \\
{ }^{1} \text { North-West University, } \\
\text { Potchefstroom, South Africa }\end{array}$} \\
\hline \multicolumn{2}{|c|}{$\begin{array}{l}\text { Correspondence to: } \\
\text { Tanya le Roux }\end{array}$} \\
\hline \multicolumn{2}{|c|}{$\begin{array}{l}\text { Email: } \\
\text { tanya.leroux@nwu.ac.za }\end{array}$} \\
\hline \multicolumn{2}{|c|}{$\begin{array}{l}\text { Postal address: } \\
\text { North-West University, } \\
\text { Private Bag X6001, } \\
\text { Potchefstroom 2520, } \\
\text { South Africa }\end{array}$} \\
\hline \multicolumn{2}{|c|}{$\begin{array}{l}\text { Dates: } \\
\text { Received: } 13 \text { Aug. } 2012 \\
\text { Accepted: } 12 \text { Dec. } 2012 \\
\text { Published: } 24 \text { Jan. } 2013\end{array}$} \\
\hline \multicolumn{2}{|c|}{$\begin{array}{l}\text { How to cite this article: } \\
\text { Le Roux, T., 2013, 'An } \\
\text { exploration of the role of } \\
\text { communication during } \\
\text { the in-crisis situation', } \\
\text { Jàmbá: Journal of Disaster } \\
\text { Risk Studies 5(2), Art. \#67, } \\
9 \text { pages. http://dx.doi.org/ } \\
10.4102 / \text { jamba.v5i2.67 }\end{array}$} \\
\hline \multicolumn{2}{|c|}{$\begin{array}{l}\text { Note: } \\
\text { 1st Biennial Conference, } \\
\text { Southern African Society for } \\
\text { Disaster Reduction (SASDiR), } \\
09 \text { to } 11 \text { October 2012, } \\
\text { Potchefstroom, South Africa. }\end{array}$} \\
\hline \multicolumn{2}{|c|}{$\begin{array}{l}\text { Copyright: } \\
\text { (C) 2013. The Authors. } \\
\text { Licensee: AOSIS } \\
\text { OpenJournals. This work } \\
\text { is licensed under the } \\
\text { Creative Commons } \\
\text { Attribution License. }\end{array}$} \\
\hline \multicolumn{2}{|l|}{ Read online: } \\
\hline 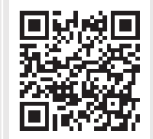 & $\begin{array}{l}\text { Scan this QR } \\
\text { code with your } \\
\text { smart phone or } \\
\text { mobile device } \\
\text { to read online. }\end{array}$ \\
\hline
\end{tabular}

'The critical component in crisis management is communication', but somehow the vague concept of 'communication' is always cited as a problem in in-crisis situations. Furthermore, available corporate communication literature mainly focuses on pre- and postcrisis reputational communication, relying only on following lists or a linear one-way push of information for the in-crisis stages. The exploratory method of reflective or interpretive action research of a hazardous material emergency desk-top simulation exercise was used to examine (1) what is meant by the term communication in the in-crisis situation, and (2) the contribution that corporate communication and the corporate communication practitioner can make during an in-crisis situation. This study found that there is confusion regarding the term communication, but even more, that each person involved also interpreted the term slightly differently, which could easily lead to confusion and/or the creation of an unclear common operating picture. The extent of the contribution that the corporate communication practitioner, as conduit of the corporate communication discipline, can make is also discussed. This paper comes to the conclusion that the contribution of corporate communication to the in-crisis situation will greatly add to the successful clearing up of an emergency situation.

\section{Introduction}

Authors and response agencies agree that ' $[t]$ he critical component in crisis management is communication' (Coombs 2012:17). However, this critical component - the vague concept of communication - is repeatedly cited as a major problem that limits effective functioning in the incrisis situation (International Wildland Fire Summit 2003; Reid \& Van Niekerk 2008:246).

In addition, crisis communication literature does not provide many answers to this conundrum, for the following reasons:

- Available corporate communication literature focuses mainly on pre- and post-crisis reputational communication (Avery et al. 2010:192).

- Articles with a focus on the in-crisis situation focus chiefly on the organisation's expected technical reaction communication to the crisis, that is, who to phone to activate response agencies (Avery et al. 2010:192; Littlefield et al. 2012:248).

There is thus a need for more information and research on communication between response agencies, and between response agencies and other stakeholders, for the in-crisis situation (Hale, Dulek \& Hale 2005:114). Here, in-crisis communication includes ' ... the collection and processing of information for crisis team decision making along with the creation and dissemination of crisis messages to people [inside and] outside of the team' (Coombs 2012:20).

Communication can make a great contribution during the in-crisis stage by assisting the decisionmakers during the response stage, empowering them to get the best possible result for the crisis. Appropriate in-crisis communication can thus assist to lessen the crisis and aid in crisis recovery (Hale et al. 2005:112,114). Specifically, corporate communication practitioners need to step up to the plate to unlock the value of communication during the in-crisis situation.

Against this background, this paper aims to:

- identify what is meant when referring to communication in in-crisis situations

- explore the contribution that corporate communication and the corporate communication practitioner (CCP) can make during an in-crisis situation.

The paper will start by clarifying some terms, and will then continue by framing the research questions within the applicable paradigms and theory. From there, the research method will be explained. The paper will conclude with the findings. 


\section{Standarised Terms}

This paper specifically refers to in-crisis situations, rather than incidents, emergencies or disasters. Generally incidents are accepted as being relatively minor occurrences, with emergencies indicating shortages of time and resources and an escalation above an incident (Reid \& Van Niekerk 2008:246-247). A disaster is then the next level of escalation of an emergency (Reid \& Van Niekerk 2008:247). This paper aims to incorporate all these situations, regardless of the number of agencies involved (level of response) and whether the agencies are involved across districts and or jurisdictions. The goal of this paper is not to get involved in the definition of the level of crisis (incident, emergency, disaster), but rather to provide a discussion on how communication could be utilised during the in-crisis situation.

In-crisis communication focuses on the communication between the response agencies; and between the response agencies and other stakeholders. In this paper, communication is not viewed from the business organisation's point of view, but from the response agency's point of view. Incrisis communication includes feeding information into the response agencies' decision-making teams and disseminating messages from them to people both inside and outside the team (Coombs 2012:20).

\section{Theoretical Structure of the Paper and Conceptualisation}

Table 1 summarises the conceptualisation used in this paper. Paradigms represent a scientific view that aims to organise and define the constructs used in the study (Jansen \& Steinberg 1991:7). The researcher elects to declare the paradigms used, as this forms the framework for understanding the observations or findings of the study and will make it clear to readers why certain theories were used (Babbie 2004:33; Grunig 1992:6; Steyn 2004:55).

\section{The disaster risk reduction paradigm and Incident Command System (ICS ${ }^{1}$ ) theory}

The first paradigm that frames this study is the disaster risk reduction paradigm. This paradigm implies that the focus should be on the prevention of disasters or preparedness for disasters in order to create disaster resilience. The implication is that when this is the case, disasters would be managed more easily, with less loss of life, damage to property and lower cost.

After 1994 the South African government actively moved toward the disaster risk reduction paradigm (South Africa 2005:1) by resolving to: 'adopt a new developmental approach in line with global trends by integrating risk reduction methodologies into developmental initiatives to build resilience in households, communities and areas known

1.Although this study focuses on the ics theory, the terminology used by the response agencies included referring to a joint operations centre (JOC), rather than an Incident Command Centre. Therefore, in keeping with the respondents' use of terms, the term $\mathrm{JOC}$ will be used when referring to the Incident Command Centre.
TABLE 1: Theoretical framing of the research problem.

\begin{tabular}{lll}
\hline Domain & Paradigm & Theory \\
\hline $\begin{array}{l}\text { Disaster studies } \\
\text { domain }\end{array}$ & $\begin{array}{l}\text { Disaster risk reduction } \\
\text { paradigm }\end{array}$ & $\begin{array}{l}\text { Incident Command System structure } \\
\text { theory }\end{array}$ \\
$\begin{array}{l}\text { Corporate } \\
\text { communication } \\
\text { domain }\end{array}$ & $\begin{array}{l}\text { Two-way symmetrical } \\
\text { communication } \\
\text { paradigm }\end{array}$ & $\begin{array}{l}\text { - Relationship management theory } \\
\text { Corporate communication } \\
\text { practitioner role theory } \\
\text { (strategist, manager, technician) }\end{array}$ \\
\hline
\end{tabular}

to be at risk' (Reid \& Van Niekerk 2008:245). The national disaster management framework which was then developed placed explicit emphasis on the disaster risk reduction concepts of disaster prevention and mitigation as the core principles to guide disaster risk management in South Africa (South Africa 2005:2). This risk reduction paradigm extends into responses to incidents, as rapid, effective, integrated and coordinated response would limit further damage to property and loss of life (Reid \& Van Niekerk 2008:245). The South African National Disaster Management Framework (SANDMF) places specific focus on communication and communication flow during incidents by identifying this aspect as one of the three enablers of the SANDMF (South Africa 2005:3). Communication responsibilities are even assigned to the Provincial Disaster Management Centre (DMC) and Municipal DMC (South Africa 2005:13-14).

For the purposes of this study, it would therefore imply that the various agencies involved in the study understand the importance of preparation, and that each agency should be prepared with an incident contingency plan to effectively manage each possible scenario so as to ensure cooperation between agencies. The contingency plans also need to be circulated amongst agencies.

The above suggests that a coordinated national incident management system is needed in South Africa to expedite coordination and cooperation between agencies. However, South Africa differs from other countries such as the UK, Canada, Australia and the USA, in terms of the structure of its response agencies. Therefore, given the lack of a standardised response system (Reid \& Van Niekerk 2008:245), South Africa needs to develop a system that accommodates this country's specific needs: political, administrative and cultural systems, as well as customs and values (International Wildland Fire Summit 2003:1).

Currently, agencies apply a hybrid of the Incident Command System (ICS) structure. The ICS structure is a method of dealing with crisis in which response agencies can work together, and where communication is aided through the structure used (International Wildland Fire Summit 2003:3).

In this structure, the first agency on the scene enacts the incident commander (IC) position until it is resolved, a better qualified or higher-ranking person arrives, or the IC appoints another. The main idea is to keep unity of command and the span of control as small as possible. As soon as more than one agency arrives at a scene, a venue operations centre (VOC) is formed onsite: this is where the agencies will coordinate their activities. If necessary, a joint operations centre (JOC) is formed with higher-ranking officials taking over decision- 
making and planning functions. This system answers the questions as to 'who is in charge?' and 'what is my job?', and it promotes communication and coordination (Ministry of Environment, British Columbia 2002). This flexible structure can expand or shrink as necessary, and aids cooperation and communication flow in an incident situation (International Wildland Fire Summit 2003:1). It is also easy to follow, and, as stated by the International Wildland Fire Summit (2003:2), it is a proven model in many countries.

\section{The two-way symmetrical paradigm, relationship management theory and communication practitioner role theory}

The two-way symmetrical paradigm was conceptualised after analysing the findings of the Excellence Study within the corporate communication domain. The focus of this paradigm is that mutually beneficial, long-term relationships that balance the interests of all parties (creating partnerships), can be built between and their stakeholders, through transparent and ethical communication (Grunig 1989:38, 40; 2001:14; Grunig, Grunig \& Dozier 2002:11; Grunig \& White 1992:42-43). The concepts of power sharing and recognising that an organisation's or stakeholder's behaviour can change because of the two-way symmetrical communication used are central to this paradigm (Grunig \& White 1992:39; Grunig et al. 2002:10, 308-309). In this study, the two-way symmetrical paradigm argues that communication between agencies, and between agencies and other stakeholders, during the incrisis situation should strive to be conducted within the twoway symmetrical paradigm in order to maintain mutually beneficial relationships.

The outcomes of a response agency's or stakeholder's behaviours, including their communicative actions, forms a relationship between themselves and other stakeholders. Therefore the relationship management theory is also used.

The quality of long-term relationships with their various stakeholders, managed through two-way symmetrical communication, allows the response agencies the freedom to achieve their mission, reduce the costs of regulation and litigation, reduces the risk of implementing decisions (as more knowledge on the possible ramifications is available) and limits negative publicity (Grunig 2006:3, 6; Grunig et al. 2002:xi, 10, 11; Grunig \& Haung 2000:32; Hon \& Grunig 1999:7-9, 11; Phillips 2006a:34, 35; 2006b:212).

Relationships are determined by evaluating the following relationship indicators (Hon \& Grunig 1999:1-40; Grunig 2002:2; Grunig \& Haung 2000:43-47; Hon \& Grunig 1999:3):

- The extent to which the relationship is expected to be an exchange relationship. This entails whether parties expect something in return from one another, or expect interaction to be rewarded with something. For instance, citizens pay taxes and therefore expect up-to-date emergency services.

- The extent to which the relationship is expected to be a communal relationship. Here, parties are genuinely concerned about one another's wellbeing and, as a consequence, provide benefits to one another, regardless of whether they will receive something in return. For example, citizens not only expect emergency services to assist them, but also expect the emergency personnel to be genuinely concerned for them as individuals.

- Control mutuality indicates the power balance within the relationship that is acceptable to both parties and cognitively judged. Jahansoozi $(2006: 77,78)$ states that, in reality, there will always be a power mismatch between the two parties. The question is whether this mismatch is acceptable to all stakeholders.

- Trust indicates the level of confidence in each other, particularly pertaining to integrity (fair and just), dependability (does what it says it will do) and competence (has ability to do what it said it will do). This is also judged from a cognitive point of view.

- Commitment is seen as the willingness to spend energy on maintaining and growing the relationship. It is judged emotionally.

- Satisfaction is the extent to which the relationship is positively experienced. This encompasses affection and is judged emotionally.

Ideally, agencies and stakeholders should, by means of their communication during an incident, be aware that their actions and communication influence their relationships with others, on the various levels discussed above. Communication practitioners are trained to do this job.

Public relations practitioners in South Africa are defined in terms of the roles that they perform. In South Africa, the roles of the strategist, manager (with or without strategic intent) and the technician have been defined (Everett 2006:1-65; Steyn 2000a:21; 2000b:37-38). These roles are, however, described within the business organisation context.

Also, keep in mind that the practitioner's role is influenced by the individual's environment (Hogg \& Doolan 1999:597), which can force a person to perform various combinations of the above-mentioned roles.

\section{Strategist}

The public relations strategist practises public relations with a macro level view. The focus is on analysing the environment (environmental scanning), specifically, on the boundary-spanning role (Grunig 2001:6; Steyn 2007:139, 141; Steyn \& Puth 2000:17). In this role, the practitioner analyses the environment and interprets this information for management and, in return, interprets the organisation's viewpoints for stakeholders (De Beer 2001:2; Grunig 2001:6; Grunig et al. 2002:2; Moss, Warnaby \& Newman 2000:301; Steyn 2007:139, 141; Steyn \& Puth 2000:17, 19, 20; Warnaby \& Moss 1997:13). The practitioner thus scans the environment for issues at the societal level and their consequences for the organisation, and needs to communicate these risks back to management for consideration in strategic decision-making (Steyn 2007:146). Specifically, in a more volatile organisational environment, this risk-reducing role of the practitioner would become more important (Lauzen \& Dozier 1992:205; Moss et al. 2000:283). 
The strategist furthermore focuses on actions such as, amongst others, relationship building with stakeholders and reputation-risk management, and is also responsible for public relations strategy (Everett 2006:101-102; Everett \& Steyn 2006:25-26; Steyn \& Puth 2000:17-18). In addition, the strategist is also tasked with liaising with the media (Everett 2006:101-102; Everett \& Steyn 2006:25-26; Steyn \& Puth 2000:17-18), as they are well versed in the organisation's views and understand the stakeholder's expectations.

Within an in-crisis situation, from the response agencies' point of view, there is the need for a strategist. Since the practitioners are familiar with the views, challenges faced by, and expectations of the agencies, and understand the needs of stakeholders, they can, firstly, feed information about stakeholders into the crisis decision-making hub (VOC or JOC). Secondly, they can anticipate possible problems with stakeholders and pre-warn decision-makers on actions to be taken or not to be taken. Lastly, they can also liaise with the media, as they should already have a good relationship with them.

\section{Manager}

In the role of manager in South African public relations, the practitioner gives input on the functional strategy by advising on consequences of behaviour; suggests communication messages; and formulates strategy and plans for messages to be communicated outside the organisation at the meso level (functional, departmental or divisional level) (Steyn 2000b:31; 2007:146; Steyn \& Puth 2000:20). The South African manager role (and technical role as discussed below) both form part of the expressive tasks. The expressive tasks focus on building relations with stakeholders by helping the organisation to express and explain itself to stakeholders (Steyn 2000b:29-30; 2003:24; 2004:71-72). The relevant duties include, amongst others, developing and implementing public relations strategy (on the meso level); developing plans; managing; leading the public relations department; and educating management on their communication responsibilities and capabilities (Everett 2006:102-103; Steyn 2007:140-141).

Steyn (2007:140-141) further distinguishes between a managerial role with and without a strategic mandate in the South African environment. Managers with a strategic mandate complete their tasks in alignment with the organisation's strategic goals, whereas managers without a strategic mandate will implement functional plans only to support strategies, measure these, and support other functions' communication efforts.

In terms of the in-crisis situation from the response agencies' point of view, it is essential that the manager (a skilled manager with a strategic mandate) be able to formulate messages that align with the goals of the decision-making team.

The tasks of managing and leading a public relations department are not seen as necessary during a crisis situation, as it is expected that various practitioners from different agencies would work together as peers during a crisis situation.

\section{Technician}

The South African public relations technician's role, similar to those identified in other countries, is performed at the micro level. It is used to express the organisation's strategy and plans, as devised by the manager on an operational level, to stakeholders (Steyn 2003:23-24; 2007:147; Steyn \& Puth 2000:21). Technician thus helps to convey the organisation's activities to stakeholders by producing communication products such as writing and editing communication publications, producing audiovisual messages, creating graphics, and communicating on social media (Steyn 2000b:26, 31; 2007:147; Steyn \& Puth 2000:21). The technician will also be able to feed stakeholder messages received via various media back to the management.

In terms of the in-crisis situation and from the response agencies' view, the technician is needed to package and send messages, and receive messages and feed them back to the crisis decision-makers.

In summary, a useful crisis management structure is crucial for the agencies attending an incident, as it will guide, support and encourage good communication flow in order to maintain mutually beneficial relationships between response agencies, and between response agencies and stakeholders.

Given the above theories on the crisis management structure and communication for good relationships, the following factors should be taken into account.

\section{A few important literature aspects pertaining to the study}

\section{The influence of stress on communication}

Keep in mind that during the in-crisis time there is complexity and ambiguity, and decisions need to be made (Hale et al. 2005:114), all during a time when communication flow increases significantly (Hale et al. 2005:116).

During the in-crisis situation, response agencies move between the following steps pertaining to communication (Hale et al. 2005:120-123):

- Observation: This entails gathering data from others through communication and then identifying any possible missing data for the scenario at hand.

- Interpretation: In this step, designated persons assign meaning to the observed information in order to create a picture in their mind of the scenario; in other words, to create a situational understanding.

- Choice: This is where the crisis management team communicates with one another in order to make decisions regarding the crisis situation.

- Dissemination: Where information or decisions made by the crisis management team are sent to others for them to act on, or information is sent to other stakeholders.

However, these seemingly easy-to-follow steps become extremely challenging in troubled and uncertain times, when people are working under severe pressure, and experience stress, fear and anxiety, all of which influence good judgement and the ability to make decisions (Ulmer, Seeger \& Sellnow 2007:130). 
Stress thus negatively influences communication by limiting people's skills with regard to observation, as explained above, which then leads to a lack of or missing information on which decisions are then made under great pressure. Finally, it leads to incorrect information being further disseminated to response agencies at the scene or stakeholders.

\section{Managing the media}

The public is represented by the media and the media therefore has a right to information (Newsom, Turk \& Kruckeberg 2004:338). It is important to keep in mind that the information passed to and portrayed by the media will influence the stakeholders' trust in and view of the competence of the response agencies.

Response agencies should, during the crisis, try to view the media as a partner that can assist in the dissemination of messages, and not as a force that should be managed strictly and negatively (Veil 2009:1-8).

\section{Emergency learning}

Emergency situations and exercises provide response agencies with the opportunity to learn from their mistakes in order not to repeat the same mistakes, and in the end be better prepared for any emergency (Crandall, Parnell \& Spillan 2010:14). However, response agencies seem to think that discussing lessons learnt after an event and then making changes to plans or policies are sufficient. In order to become emergency-resilient, response agencies need to apply emergency learning.

Typically, response agencies translate the lessons learnt from emergency situations and/or exercises into new norms, plans, tools and/or infrastructure that are considered to assist them with future emergency situations (Elliot \& Macpherson 2010:572, 577). However, the emergency learning attitude argues that the response agencies not only need to do that, but must also learn the ability to adapt what has been learnt to new, emerging scenarios. Emergency learning thus argues that lessons learnt from previous exercises become real only when they can be practised and applied to any new scenario (Elliot \& Macpherson 2010:572).

\section{Research method}

In this study, an exploratory research approach is used to explore and explain the little-known, relatively new phenomenon of in-crisis communication within the South African environment (Babbie 2004:87, 89; Rubin, Rubin \& Piele 2005:206; Stebbins 2001:2). As used in this study, exploratory research is used to test the feasibility of further studies and methods to be employed in the studies, to satisfy the researcher's curiosity and desire for a better understanding and in this process create new ideas (Babbie 2004:88; Stebbins 2001:9). Exploratory research is traditionally qualitative (Stebbins 2001:6, 8-10), as used in this study.

The data was gathered by means of the reflective action of interpretive action research (McNiff \& Whitehead 2011:11) during (and after) a desktop hazardous material spill crisis simulation.

The desktop simulation included a hazardous material spill scenario in the town of Potchefstroom (Tlokwe Municipality), North-West Province, South Africa. The simulation scenario was as follows: a vehicle carrying radioactive material (yellow cake) was hijacked. The tracking system of the vehicle was removed and the support vehicle for the truck was neutralised. The SAPS air wing then spotted the vehicle en route through Potchefstroom. A chase ensued, which culminated in the hijacked vehicle colliding with seven stationary vehicles next to the Mooi River Mall and Mooi River. In the process, the tanker was damaged and overturned.

All the role players pertaining to such an event were present and included SAPS (various sections and divisions), traffic department, EMRS (including private ambulance companies), fire brigade, hospitals, mall management, the company owner of the vehicle, and so on. These agencies acted as players in the scenario (Federal Emergency Management Agency 1992:13). Although invited to do so, players did not submit emergency plans before the desktop exercise.

A brief of the scenario was given to those involved and a date and time arranged to have the desktop simulation. There was thus no surprise element to the incident.

First responders to the scene were located in a separate room (VOC) and had radio contact with decision-makers in the incident command centre (JOC). Players were called into the various locations when needed. Unfortunately, players could not be accommodated in a separate room and were privy to information before joining the incident command centre or first responders.

Two controllers (Federal Emergency Management Agency 1992:13) were employed to ensure that the exercise went according to plan, and were available to answer participants' questions and feed new information into the scenario. Fifteen evaluators (Federal Emergency Management Agency 1992:14) were employed to observe the action and gather data on specific elements of the process. Two evaluators specifically focused on communication within the scenario. The evaluators did not interfere with the players or controllers.

\section{Findings, discussion and recommendations \\ What is meant when referring to communication in in-crisis situations?}

The data gathered at the simulation illustrate that when referring to the term communication in in-crisis situations, the meaning of the term is not clear. The term 'communication' is used to refer to:

- One person talking to another or sending a message to another, for example, 'did you communicate that to him?'. 
- The channels of communication used by response agencies, such as cell phones and radios, for example, 'the communication [the radios] failed'.

- The standard expected messages sent between the various agencies, for example, 'has the fire brigade communicated yet?' [has the fire brigade declared the scene safe yet?].

- The flow of messages to or from the VOC and JOC, for example, 'there is a bottleneck with communication' [messages are not flowing into or out of the VOC/JOC].

- Visual media that would assist the rescue and recovery process such as maps, for example, 'I had no communication of the scene' [I had no clear picture (map) of the scene].

- An umbrella term for the management of communication during the crisis, for example, 'communication during the crisis was a problem'. In this instance, communication is used as an umbrella term for messages, channels and information flow, as well as any other aspect pertaining to communication.

- An umbrella term for pre-crisis meetings that are held between agencies, for example, 'we communicate once a month at the log joint ' [we all meet up once a month at the log joint meeting]. In this instance, communication is seen as being similar to attending a meeting. In addition, from discussions with the various agencies, it would seem that not all the agencies attend the meetings regularly. Furthermore, different representatives are sent to each meeting, negating the creation of a familiar face or contact at each agency.

In other cases, agencies communicate without realising that they are engaging in a form of communication. For instance, wearing marked clothing communicates to other agencies and bystanders the identity of the particular person and the reputation of the agency. The actions and conduct of that person will also further influence the reputation of the agency.

Another method of symbolic communication that is used is the placing of a traffic cone on an agency vehicle, to indicate that that is the incident command. In cases where agencies do not have good relations and see each other as competition, two or more agencies have been reported to place cones on their vehicles at the same situations. As can be expected, this clearly communicates a message of confusion and rivalry, which could hamper any communication that would assist in a quick response and recovery.

Additionally, agencies also use a lot of jargon during a crisis situation in their communication between and within agencies.

From the above, one can deduce that the meaning of the term communication is not clear when used in the in-crisis situation. Each person also interprets the term slightly differently, which can easily lead to confusion and/or the creation of an unclear common operating picture. In an in-crisis environment, where people are under pressure and need to make decisions quickly, any confusion or miscommunication is a serious concern.
When taking the relationship management theory into account as discussed above, one can understand that the abovementioned miscommunication could lead to stressed relationships between agencies.

It is recommended that agencies be educated in what communication entails, how it works, the influence of a crisis on communication, and the link between communication and relationship-building. Attention should also be given to facilitating understanding between agencies during this process, in order to create understanding for each other and ultimately to build healthy relationships. This can be done by discussing examples of where agencies worked together, highlighting aspects of the relationship (trust, satisfaction, etc.) that were harmed through poor communication, and exploring how this could be improved on in future.

\section{Exploring the communication challenges in the in-crisis situation}

In order to understand the contribution that a corporate communication practitioner can make to the in-crisis situation, one needs to explore some of the communication challenges identified during the simulation. In this discussion, the findings will be discussed, as well as recommendations made where appropriate.

\section{Communication channel failure}

Communication channels can fail during a crisis situation. Response agencies make use of cell phones and two-way radios to communicate during a crisis. They have previously experienced the cell phone infrastructure becoming overloaded, which resulted in lost signals and limited cell phone network coverage in the area in which they need to work. Radio communication has also suffered in the past, as so many messages had to be sent via two-way radios that too much communication was sent on a single bandwidth, limiting the sending of important messages. In another instance, the radio communication failed as a result of technical errors.

Communication channel solutions that can act as back-up to overcome these obstacles, need to be investigated.

\section{Reporting into the joint operations centre}

Although communication within agencies is usually guided by protocols, problems can still occur. Some agencies have experienced two or more people reporting from the scene into the JOC, with differing reports. This created confusion. In addition, each agency's call centre also needs to be able to deal with the messages associated with a crisis situation, whilst still managing the normal calls that come in.

As people are stressed during a crisis situation, they tend to revert to their home language when reporting to their call centre and the JOC. Since South Africa has 11 official languages, people reverting to their home language can create problems, as not all people understand all the languages. 
Response agencies need to be trained in communication. As confusion in messages can be expected during a crisis, agencies should be trained in the technique of confirming messages and the acknowledgement of messages to limit confusion. During communication training, agencies can also be sensitised to the implications of reverting to their home languages.

\section{Information flow to and from the joint operations centre}

During a crisis situation, the JOC receives large numbers of incoming messages, as well as sending a large number of messages to and from response agencies and other stakeholders. Their ability to facilitate this communication flow will directly impact the success of clearing up the current crisis and maintain good relationships with the stakeholders, in view of working together again in the future. Since all the people from the various agencies are focused on their specific emergency response tasks, they are not free to focus only on facilitating communication, which leads to the development of serious communication bottlenecks.

The JOC should ideally have dedicated persons with no other responsibility than to facilitate the incoming and outgoing messages from response agencies to the incident command and vice versa. These persons do not need to have a specific communication background, but need to be familiar with the incident command structure and the use of cell phones, radios and the like. These persons should also keep a record of all communications. Their goal would be to facilitate communication flow to and from the JOC, and through this process speed up the reaction time and allow the JOC staff time to make decisions. Logistically, these persons should sit in close proximity to the JOC. They could even be situated in the same room as the JOC, as long as they do not disrupt the JOC processes.

An issue that does hamper JOC communication, even if communication facilitators are appointed, is the fact that the roles and responsibilities of the ICS system are not clearly defined, understood and applied by all involved in the crisis. For instance, in this study, the role of each person in the JOC was not clearly understood as explained by this quote from a participant: 'Who should be taking charge of planning?'. Although enhanced communication would greatly assist in the in-crisis situation, defining the roles within the incident command system would also assist in enhancing communication during this period.

Communication from the JOC to other stakeholders apart from the response agencies and media, should also receive attention. For instance, communication must be made with families and a record kept of the communication for future reference. The corporate communication practitioner could assist in communication with stakeholders. The practitioner, as stakeholder relationship custodian, brings the voice of the stakeholder network on a societal level into the JOC. This involves obtaining information and feeding it into the JOC, and disseminating information from the JOC to stakeholders (Grunig et al. 2002:2; Steyn 2000:30) in order to assist the JOC team in making decisions.
The practitioner should identify the stakeholders involved and the protocol involved in communicating with each stakeholder. This must be displayed prominently for all in the JOC to see. Numbers of the appropriate contacts should be available at the incident command and be clearly communicated to those working on the scene. Included in the protocol would be the decision to use social media (e.g. Facebook and Twitter) in the in-crisis situation. Furthermore, the practitioner needs to be fluent in at least English and Afrikaans, and the local language, in this case Tswana (since the study focused on the North-West province).

Communication with the media should also receive specific specialised attention from the communication practitioner, as response agency personnel are not necessarily equipped to deal with media enquiries and need to focus their attention on response and recovery. Just as the other functions report back during the incident command, the media liaison person should also be given time to report on the media developments.

The media should not be seen as a necessary evil, but rather as a resource that can be utilised to assist the incident command in managing the situation. In the simulation, however, the media was seen as a threat, being kept at arm's length and passed from person to person. This resulted in the media not being managed in such a way as to make the best use of the media or to create positive relationships with the media and other stakeholders.

Ideally, media calls should come into the incident command on a separate line, allowing the incident command line to stay open for response agency communication. A record should also be kept of what messages were sent to which media groups at what time. The practitioner must also know when to include experts in media briefings, and must have media information available that can be used during times when there is a necessary lull in the communication.

\section{Involving corporate communication practitioners in the joint operations centre}

Lastly, corporate communication practitioners are not usually involved in the JOC. In the simulation, communication practitioners were called in and consulted only when the incident commander was swamped with media enquiries. In a discussion with various parties after the simulation, it was stated that in most cases the media are referred to the communication practitioners, who are not available after office hours. The result was that relationships with stakeholders, and specifically the media, risked being severely damaged.

Furthermore, since communication practitioners are not usually involved in such instances, they were also at a loss as to what was needed from them, as they did not understand the agencies' structures and were not privy to the information on the background of the crisis situation.

The abovementioned finding, together with the confusion on the use of the term 'communication', highlights the need 
for communication specialists to be integrated with the teams dealing with the in-crisis situation. Communication practitioners need to be included in the management of the crisis as soon as possible, during or after office hours.

\section{The contribution that the corporate communication practitioner can make during an in-crisis situation}

The corporate communication practitioner (the practitioner) is the knowledgeable expert on the application of communication towards building and maintaining relationships, and therefore represents the contribution that the discipline can make to the in-crisis situation. It does, however, need to be added that practitioners who can adapt previous lessons learnt to the current scenario and apply emergency learning, will be more successful than practitioners who are not able to do this. For an in-crisis situation, separate media liaison and stakeholder liaison persons can be appointed, or they can be a single person. The focus will thus be on actions that the practitioner can take.

As a media liaison officer, the communication practitioner must:

- When entering the JOC:

1. Assess if any media calls have already been handled and what has been said to whom.

2. Understand the crisis situation and current message that can be disseminated. Messages must be confirmed and signed-off by the IC.

3. Inform the VOC of the contact number for media and other stakeholder queries and confirm that such requests for information should be directed to the JOC.

4. List all possible stakeholders and their contact details, and ensure that all are included in communication as appropriate.

- Give feedback to the IC on updates to the media and communication with other stakeholders.

- Advise on new messages that can be sent, and collaborate and agree on the messages with the IC. The messages, time and to whom they were sent should be annotated in brief on a whiteboard. This will assist with keeping the 'story line', keeping agreement on the messages sent, and assisting in the anticipation of further information needs from stakeholders and the media.

- Assess the possibility and need for the use of social media to keep stakeholders updated.

- In times when new messages are not available, the media and stakeholder relations officer should give the media information on the town or area that has been compiled beforehand.

- In cases where there are questions that demand specialist knowledge, a specialist must be contacted and asked to join the team and prepared for a media briefing. Media briefings should be held only when there is a need for the media to speak to a third person such as a specialist.

A stakeholder liaison practitioner (for stakeholders such as family members of the injured, the mayor of the city, farmers, organised businesses, etc.) should focus on working on the macro (societal) level in the typical boundary-spanning role (acting as a liaison between the JOC and key stakeholders). The officer should thus keep the bigger picture in mind, by identifying the key stakeholders and their issues, and constantly asking the question: 'How does this crisis/new development influence my key stakeholders?'. From there, this person should firstly obtain information and feed it into the JOC, and secondly disseminate information from the JOC to stakeholders in such a way as to maintain good stakeholder relationships (Grunig et al. 2002:2; Steyn 2000b:30).

The goal for this person is thus to guide the key stakeholders through the crisis situation. With some of the stakeholders, the officer should act proactively by trying to contact them first (if possible and reasonable), for example, the local media, and mayor; and in other cases the communication will be reactive, for example, with family members.

The activities carried out should thus include:

- Identifying strategic stakeholders and issues to manage.

- Feeding this information into the strategic decision-making process to ensure the safeguarding of relationships with stakeholders, as well as managing issues and avoiding conflict. The implications of strategic decisions on stakeholders are also explained to the JOC (environmental scanning, issues management, boundary spanning). It may also be necessary to explain to top management the impact their behaviour could have on key external stakeholders (media, investors, communities).

- Acting as an early warning system to the incident command on further issues that could arise.

- Reputation risk management, by reducing uncertainty in strategic decision-making by interpreting the external environment to top management.

- Facilitating communication to and from stakeholders through whatever channels are needed.

- Safeguarding, building and maintaining stakeholder relationships by applying two-way symmetrical communication, as far as possible.

\section{Conclusion}

Brändström et al. (2004, in Elliot \& Macpherson 2010:574) stated that: '[a]t the heart of crisis lies their unacceptability, which motivates actors to prevent their recurrence'. One can add that this unacceptability also urges actors to respond, recover and end the crisis as soon as possible with the least amount of damage done and lives lost. This can, however, only be done when response agencies use each situation as a learning opportunity and apply emergency learning, specifically that pertaining to communication.

Improvement on the complex mix of communication facets mentioned above, as observed during the Potchefstroom (Tlokwe Municipality) desktop hazardous material spill crisis simulation, when managed correctly, can greatly assist the JOC team in successfully resolving a crisis situation. 


\section{Acknowledgments Competing interests}

The author declares that she has no financial or personal relationship(s) which may have inappropriately influenced her in writing this paper.'

\section{References}

Avery, A.J., Lariscy, R.W., Kim, S. \& Hocke, T., 2010, 'A quantitative review of crisis communication research in public relations from 1991 to 2009', Public Relation Review 36, 190-192. http://dx.doi.org/10.1016/j.pubrev.2010.01.001

Babbie, E., 2004, The practice of social research, 10th edn, Wadsworth/Thompson Learning, Belmont, CA.

Coombs, W.T., 2012, Parameters for crisis communication', in W.T. Coombs \& S.J. Holladay (eds.), The handbook of crisis communication, pp. 17-53, Blackwell Publishing, Chichester, West Sussex, U.K.

Crandall, W., Parnell, J.A. \& Spillan, J.E., 2010, Crisis management in the new strategy landscape, Sage, Thousand Oaks, CA.

De Beer, E., 2001, 'The perception of top communicators of senior management's expectations of excellent communication in South African companies', MA Dissertation, University of Pretoria

Elliot, D. \& Macpherson, A., 2010, 'Policy and practice: Recursive learning from crisis', Group \& Organization Management 35, 572-605. http://dx.doi.org/10.1177/ 1059601110383406

Everett, T., 2006, 'Defining the core elements of management in public relations context: what do South African public relations managers do?' MTech Minidissertation, Cape Peninsula University of Technology, Cape Town.

Everett, T. \& Steyn, B., 2006, 'Defining the core elements of management in the public relations context in South Africa: an international comparative study', paper presented at the 8th Annual EURPRERA Conference, Carlisle, UK, 06-09 paper presented
September 2006.

Federal Emergency Management Agency, 1992, Hazardous Materials exercise evaluation methodology, Federal Emergency Management Agency, USA

Grunig, J.E., 1989, 'Symmetrical presuppositions as a framework for public relations theory', in C.H. Botan \& V. Hazleton (eds.), Public relations theory, pp. 17-44, Lawrence Erlbaum, Hillsdale, NJ.

Grunig, J.E., 1992, 'Communication, public relations, and effective organizations: an overview of the book', in J.E. Grunig (ed.), Excellence in public relations and communication management, pp. 1-28, Lawrence Erlbaum, Mahwah, N.J.

Grunig, J.E., 2001, 'The role of public relations in management and its contribution to organizational and societal effectiveness', paper presented in Taipei, Taiwan, 12 May 2001, viewed 27 January 2006, from http://www.instituteforpr.org /topics/ organizational-societal-effectiveness/

Grunig, J.E., 2002, 'Qualitative methods for assessing relationships between organizations and publics', viewed 27 January 2006, from http://www.instituteforpr.org/iprwp/ wp-content/uploads/2002_AssessingRelations.pdf

Grunig, J.E., 2006, 'After 50 years: the value and values of public relations', paper presented at the Institute for Public Relations' 45th Annual Distinguished Lecture presented at the Institute for Public Relations' 45th Annual Distinguished Lecture,
Yale Club, New York, 09 November 2006, viewed 01 June 2007, from http://www. instituteforpr.org/iprwp/wp-content/uploads/Grunig_Lecture_06.pdf

Grunig, J.E. \& Haung, Y., 2000, 'From organizational effectiveness to relationship indicators: antecedents of relationships, public relations strategies, and relationship indicators: antecedents of relationships, public relations strategies, and relationship management: a relational approach to the study and practice of public relations, management: a relational approach to the stud
pp. 23-53, Lawrence Erlbaum, Mahwah, N.J.

Grunig, J.E. \& White, J., 1992, 'The effect of worldviews on public relations theory and practice', in J.E. Grunig (ed.), Excellence in public relations and communication management, pp. 31-64, Lawrence Erlbaum, Mahwah, N,J.

Grunig, L.A., Grunig, J.E. \& Dozier, D.M., 2002, Excellent public relations and effective organizations: a study of communication management in three countries, Lawrence Erlbaum, Mahwah, N.

Hale, J.E., Dulek, R.E. \& Hale, D.P., 2005, 'Crisis response communication challenges: Building theory from qualitative data', Journal of Business Communication 42(2) April, 112. http://dx.doi.org/10.1177/0021943605274751

Hogg, G. \& Doolan, D., 1999, 'Playing the part: practitioner roles in public relations', European Journal of Marketing 33(5, 6), 597-611.
Hon, L.C. \& Grunig, J.E., 1999, Guidelines for measuring relationships in public relations: booklet prepared for the Institute of Public relations Commission on PR Measurement and evaluation, IPR, Gainesville, FL.

International Wildland Fire Summit 2003, 'Part IV, Strategic Paper: Incident Command System (ICS)', Outcomes of the International Wildland Fire Summit, Sydney, Australia, 08 October 2003, viewed 01 June 2012, from http://www.fire.unifreiburg.de/summit-2003/3-IWFC.htm

Jahansoozi, J., 2006, 'Relationships: transparency, and evaluation: the implications for public relations', in J. L'Etang \& M. Pieczka M (eds.), Public relations: critical debates \& contemporary practice, pp. 61-91, Lawrence Erlbaum, Mahwah, N.J .

Jansen, N. \& Steinberg, S., 1991, Theoretical approaches to communication, Juta, Cape Town.

Lauzen, M.M. \& Dozier, D.M., 1992, 'The missing link: the public relations manager role as mediator of organisational environments and power consequences for the function', Journal of Public Relations Research 4(4), 205-220. http://dx.doi. org/10.1207/s1532754xjprr0404_2

Littlefield, R, Rowan, K, Veil, SR, et al., 2012, “'We tell people. It's up to them to be prepared." Public relations practices of local emergency managers', in W.T. Coombs \& S.J. Holladay (eds.), The handbook of crisis communication, pp. 245-260, Wiley-Blackwell, Oxford, U.K.

McNiff, J. \& Whitehead, J., 2011, All you need to know about action research, 2nd edn, Sage, L.A.

Ministry of Environment, British Columbia, Canada, 2002, 'Introduction to the Incident Command System', viewed 01 June 2012, from http://www.env.gov.bc.ca/eemp/ resources/icsintro.htm

Moss, D., Warnaby, G. \& Newman, A.J., 2000, 'Public relations practitioner role enactment at the senior management level within UK companies', Journal of Public Relations Research 12(4), 277-307. http://dx.doi.org/10.1207/S1532754XJPRR1204_1

Newsom, D., Turk, J.V. \& Kruckeberg, D., 2004, This is PR: The realities of public relations, 8th edn, Wadsworth, Belmont, CA.

Phillips, D., 2006a, 'Relationships are the core value for organisations: a practitioner perspective', Corporate Communications 11(1), 34-42. http://dx.doi.org/10.1108/ 13563280610643534

Phillips, D., 2006b, 'Towards relationship management: public relations at the core of organisational development', Journal of Communication Management 10(2), 211-226. http://dx.doi.org/10.1108/13632540610664751

Reid, P. \& Van Niekerk, D., 2008, 'A model for a multi-agency response management system (MARMS) for South Africa', Disaster Prevention and Management 17(2), 244-255. http://dx.doi.org/10.1108/09653560810872541

Rubin, R.B., Rubin, A.M. \& Piele, L.J., 2005, Communication research: strategies and sources, Wadsworth, Belmont, CA.

South Africa, 2005, The National Disaster Management Framework, Notice 27534 of 2005, Government Printer, Pretoria.

Stebbins, R.A., 2001, 'Exploratory research in the social sciences', p. 67, Sage, Thousand Oaks, CA . (Sage University paper series on qualitative research methods, vol 48.)

Steyn, B., 2000a, 'The South African CEO's role expectations for a public relations manager' paper presented at the Public Relations Society of America (PRSA), Educators Academy Public Relations Research Conference, Miami, 31 March to 02 April 2000.

Steyn, B., 2000b, 'CEO expectations in terms of PR roles', Communicare 19(1), 20-43.

Steyn, B., 2003, 'A metaphorical application of the concept 'paradigm' to the public relations domain', paper presented at the Annual SACOMM (South African Communication Association) conference, Durban, June 2003.

Steyn, B., 2004, 'A metaphorical application of the concept 'paradigm' to the public relations domain', Communicare 23(1), 54-78.

Steyn, B., 2007, 'Contribution of public relations to organizational strategy formulation' in E.L. Toth (ed.), The future of excellence in public relations and communication management: challenges for the next generation, pp. 137-172, Lawrence management: challenges

Steyn, B. \& Puth, G., 2000, Corporate communication strategy, Heinemann, Sandown.

Ulmer, R.R., Seeger, M.W. \& Sellnow, T.L., 2007, 'Post-crisis communication and renewal: Expanding the parameters of post-crisis discourse', Public Relation Review 33, 130-134. http://dx.doi.org/10.1016/j.pubrev.2006.11.015

Veil, S., 2009, 'Friend vs. Foe: Viewing the Media as a Partner in Crisis Response', viewed 01 June 2012, from http://www.instituteforpr.org/topics/media-partnercrisis/

Warnaby, G. \& Moss, D., 1997, 'The role of public relations in organisations', in P.J. Kitchen (ed.), Public relations: principles and practice, pp. 6-21, Thomson Learning, London. 